\title{
METODOLOŠKI OKVIR ZA KOMUNIKOLOŠKU PROCJENU USPJEŠNOSTI VIZUALNIH KRITERIJA PARLAMENTARNIH STRANAKA U IZBORNIM KAMPANJAMA
}

\author{
Mario Plenković1, Daria Mustić2, Slobodan Hadžić3 \\ Grafički fakultet, Sveučilište u Zagrebu, Zagreb, Hrvatska \& Alma Mater Europaea - ECM \& Univerza v Mariboru, Fakul- \\ teta za elektrotehniko, računalništvo in informatiko, Inštitut za medijske komunikacije, Maribor, Slovenija'; Grafički fakul- \\ tet, Sveučilište u Zagrebu, Zagreb, Hrvatska ${ }^{2}$; PressCut, Zagreb, Hrvatska
}

\begin{abstract}
Sažetak
Vizualni elementi poruke ostvaruju svoju funkciju samo ako se poštuju kriteriji uspješnog grafičkog oblikovanja i komunikološke strukture čovjeka, koji u obzir uzimaju psihofiziološke osobine ljudskoga oka, osnovne zakonitosti percepcije i vanjske faktore (medij, mjesto izlaganja). U radu se obrađuje problematika uspješnog korištenja vizualnih elemenata kod vanjskog oglašavanja na primjeru promidžbenih jumbo-plakata hrvatskih političkih stranaka. Istraživanje je usmjereno propitivanje da li su političke stranke oblikovale svoje plakate u skladu sa profesionalnim kriterijima grafičkog dizajna. U radu se preispituje uspješnost oblikovanja ključnih vizualnih elemenata. Teorijska rasprava je provedena kroz formiranje i analizu strukture profesionalnih kriterija za korištenje vizualnih elemenata, te analizu njihove primjene na promidžbenim plakatima političkih stranaka.
\end{abstract}

\section{Ključne riječi}

Komunikologija, metodološki okvir, vizualni kiteriji, plakati, parlamentarne stranke, izborne kampanje

\section{Uvod}

Politika je sveprisutna $u$ životima građana, a to se posebno intenzivira u predizborno vrijeme. Političke stranke za samopromociju koriste sve medije i ostale raspoložive komunikacijske kanale. Politička komunikacija je uglavnom posredovana komunikacija prenošena medijima masovne komunikacije /1/. Jedan od njih, vanjsko oglašavanje, bilo samostalno ili kao dio media miksa, zauzima značajan udio u oglašavačkoj industriji. Oglasna poruka je s obzirom na veličinu jumbo-plakata uvijek „predimenzionirana", tekstualna poruka je vidljiva iz većih udaljenosti i u kretanju, naravno ako se poštuju određeni kriteriji grafičkog oblikovanja. Da bi se to postiglo, oglas bi u cijelosti trebao biti neopterećen detaljima, odnosno koncentriran na samu bit poruke. Spontano zapažanje oglasne poruke velika je prednost vanjskog oglašavanja. Ovaj medij ne traži posjedovanje tehnologije, ne podrazumijeva namjeru konzumacije medija, nije uvjetovan kupovnom moći recipijenta poruke. Bitna odrednica suvremenog života je mobilnost, što je uvidjela i oglašivačka industrija, te iskoristila činjenicu da ljudi mnogo vremena provode na otvorenom - putuju na posao, $\mathrm{u}$ škole, u nabavu, mnogo se vremena provodi na prometnicama. Temeljna karakteristika vanjskog oglašavanja je da propagandna poruka stiže i do onih koji ne gledaju televiziju, ne slušaju radio, ne čitaju dnevne novine ili specijalizirane časopise, tj. do percipiranja informacije dolazi spontano. Zbog velikog broja oglasa kojima je svakodnevno čovjek izložen i njegove fizičke nemogućnosti da uoči i zapamti sve izložene ogISSN 1333-6371 
lase, pri oblikovanju vanjskih oglasa trebalo bi poštovati profesionalne kriterije grafičkog oblikovanja vanjskih oglasa i time maksimizirati korist oglašavanja. Istraživanje je usmjereno propitivanje da li su političke stranke oblikovale svoje plakate u skladu sa profesionalnim kriterijima grafičkog dizajna.

\section{Ciljevi istraživanja}

Osnovni ciljevi istraživanja su:

- procjena vrednovanja predizbornih jumboplakata u kontekstu profesionalnih kriterija

- utvrditi da li grafičko oblikovanje jumboplakata udovoljava profesionalnim kriterijima struke

- utvrditi da li je grafički dizajn, po mišljenju studenata u struci, uopće prisutan na političkim predizbornim plakatima

- utvrditi da li su u prenošenju komunikološke željene poruke korišteni grafički alati i kriteriji vrednovanja.

\section{Metodologija i vremenske granice istra- živanja}

Istraživanje je provedeno u razdoblju od 19 . studenog do 21. studenog 2007., u tjednu prije parlamentarnih izbora, unutar perioda službene kampanje koja je trajala do 23. studenog 2007.

Polazna istraživačka hipoteza cilja na moguće istraživačke rezultate koji trebaju hipotetski ukazati na (ne)prisutnost upotrebe profesionalnih kriterija vrednovanja grafičke struke $u$ oblikovanju predizbornih plakata. Dobiveni rezultati mogu se kretati od potpuno profesionalnog pristupa grafičkom oblikovanju do minoriziranja kriterija vrednovanja grafičkog oblikovanja i uloge dobrog dizajna u prenošenju poruke.

Osnovna metoda istraživanja koja je korištena bila je anketa, što je rezultat zahtjeva ciljeva istraživanja za objektivnim i kvantitativno mjerljivim podacima o stavovima ciljane skupine.

Anketni listić je sadržavao slike pet jumboplakata vodećih hrvatskih političkih stranaka, te 30 profesionalnih kriterija grafičkog oblikovanja jumbo-plakata, čiju su prisutnost i uporabu na plakatima studenti vrednovali bodovima od jedan do pet, s tim da je jedan najniža, a pet najviša moguća ocjena.
Obrada rezultata je provođena na dvije razine:

a) skupno - studenti druge i četvrte godine grafičkog dizajna

b) komparativno - studenti druge i četvrte godine grafičkog dizajna

\section{Definiranje uzorka}

Analizom je obuhvaćena studentska populacija - studenti grafičkog dizajna druge i četvrte godine Grafičkog fakulteta, Sveučilišta u Zagrebu. Uzorak čine 33 studenta druge i 33 studenta četvrte godine grafičkog dizajna.

\section{Opis jumbo-plakata}

Jumbo-plakat ili billboard je jedan od najučestalijih formata vanjskog oglašavanja. Dimenzije billboarda mogu varirati, a najčešće dimenzije su $504 \times 238 \mathrm{~cm}$. Najčešće se postavlja uz prometnice, te općenito na mjestima velike frekfencije kretanja ljudi. Prostor za jumbo-plakat moguće je zakupiti u najkraćem roku od dva tjedna, što upućuje na to da poruka koja se želi prenijeti putem jumbo-plakata mora biti dobro osmišljena, jer se poruka ne mijenja $u$ jednom vremenskom periodu. Na cijenu jumbo-plakata utječe nekoliko faktora: veličina grada, atraktivnost lokacije, frekfencija ljudi/prometa, te da li je plakat osvijetljen ili neosvijetljen. Po tim kriterijima razlikuju se tri cjenovne kategorije, te se cijene kreću od 845 do $1280 \mathrm{kn}$ na neosvjetljenoj površini do 1320 do 1580 kn na osvjetljenoj površini (bez PDV-a) za 14 dana oglašavanja /2/. Rabati i ostali mogući dogovori oko visine cijena nisu istaknuti u cjenicima. Varijacije cijena su manje s obzirom na agenciju koja pruža uslugu ustupanja plakatnog prostora, a veće s obzirom na količinu zakupljenog prostora i vrijeme trajanja kampanje. Istraživanje poduzeća "Brandmeyer Markenberatung" u Hamburgu, objavljena 2003. potvrđuje da potrošaći prepoznaju i ispravno klasificiraju promidžbenu kampanju čak i onda kad opažaju samo jedan dio. Naučeni "key visuals" neke marke dovoljni su za jednoznačnu klasifikaciju /3/. Stoga je jako bitno kvalitetno i smisleno grafičko oblikovanje onih elemenata na plakatu za koje želimo da postanu „key visu- 
als". Uvjete poslovanja propisuje svaka agencija zasebno, dokumentom "Opći uvjeti poslovanja“. Članak 8. u Općim uvjetima poslovanja „Europlakata“ kaže: Zbog općeg javnog interesa, za vrijeme predizbornih kampanja Europlakat zadržava pravo u dogovoru s Naručiteljem, prema potrebi smanjiti opseg pojedinačnih komercijalnih akcija oglašavanja, te preuzima obvezu da dotične plakate nakon završetka predizborne kampanje izvjesi“/4/. Taj članak pokazuje da političke stranke $u$ predizborno vrijeme imaju povlašteni status koji im garantira promidžbeni prostor. U predizborno oglašavanje stranke su uložile 49.047.539 kuna, od čega 9.991.246 kuna ili $20,2 \%$ otpada na vanjsko oglašavanje /5/. Taj iznos odnosi se samo na troškove zakupa površina za vanjsko oglašavanje, bez troškova pripreme, dizajna, tiska. Razdoblje monitoringa se odnosi na vremenski period od 1.11. 2007. do 23.11. 2007. Pod vanjskim oglašavanjem podrazumijevaju se komercijalne plakatne površine ( city light, billboard i megaplakati). U usporedbi sa prošlim parlamentarnim izborima 2003. godine, ulaganja političkih stranaka u oglašavanje su se povećala, a u vanjsko oglašavanje su se smanjila. Prema istraživanju iz 2003., /6/, koje je provedeno u razdoblju od 1.9. 2003. do 30.11 . 2003., političke stranke su u oglašavanje uložile

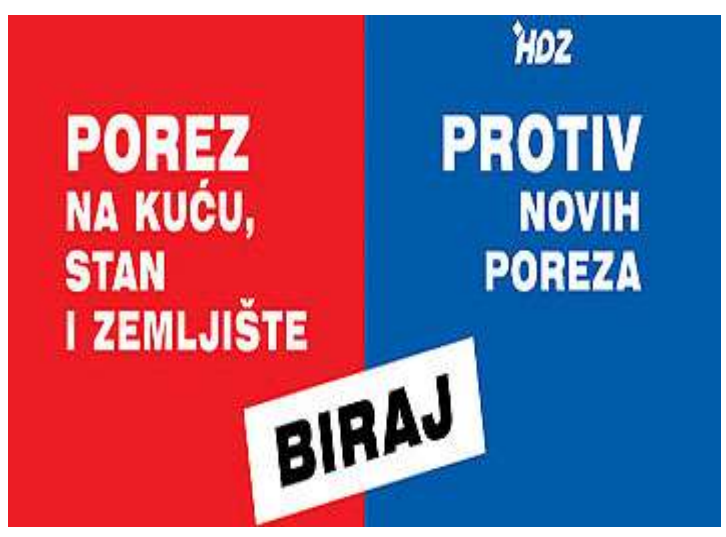

Slika 1. Plakat HDZ-a
37.000.000 kuna, a od toga je 14.900.000. kuna ili $40 \%$ izdvojeno za troškove vanjskog oglašavanja.

\section{Opis kriterija za vrednovanje jumbo- plakata}

U anketnom listiću je izdvojeno pet jumboplakata (vidi slike) i 30 profesionalnih kriterija njihovog vrednovanja. Izabrano je pet plakata koji su bili najzastupljeniji za pojedine političke stranke. Od toga su tri plakata personalizirana kroz stranačke lidere (zanimljivo je naglasiti da su na svim plakatima prisutne dvije osobe koje su na svakom plakatu specifično pozicionirane na SDP-ovom plakatu osobe se nalaze $u$ istoj vizualnoj ravnini, na HNS-ovom plakatu Vesna Pusić je vizualno, a i u stranačkoj hijerarhiji, ispred Radimira Čačića, dok su na koalicijskom plakatu HSS-a/HSLS-a stranački lideri vizualno u najudaljenijim mogućim pozicijama), dok je na dva plakata (HDZ i HSP) naglasak isključivo na komunikološkoj poruci, bez prateće fotografije.

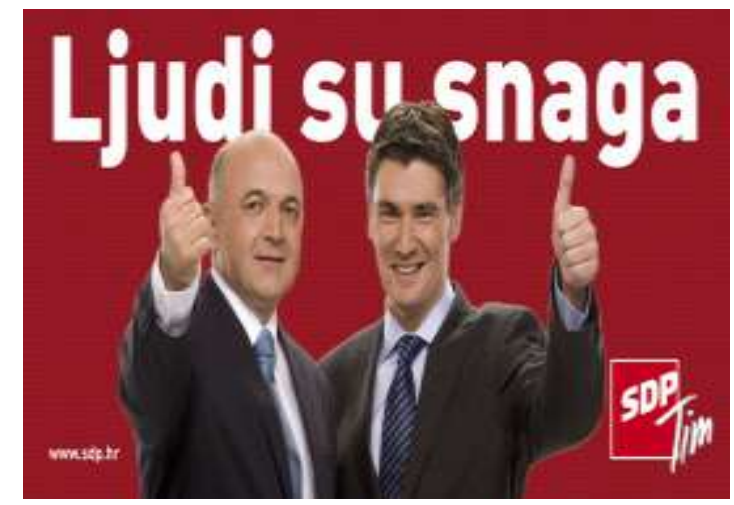

Slika 2. Plakat SDP-a 


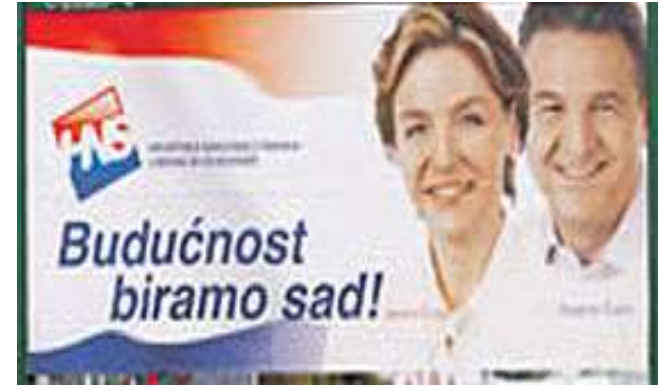

Slika 4. Plakat HNS-a

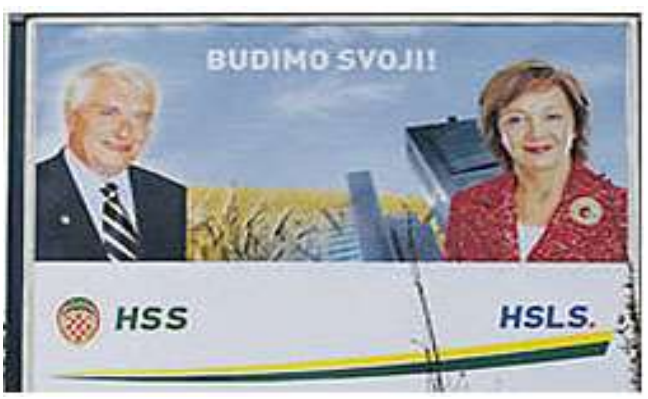

Slika 4. Plakat HSS-a/HSLS-a

30 profesionalnih kriterija su radi lakšeg snalaženja podijeljeni u 6 skupina koje sadrže kriterije koji se odnose na isti element ili sadržaj.

Prvu skupinu čine kriteriji vrednovanja koji se odnose na tipografiju, a to su:

- inovativnost (novost u oblikovanju korištenog fonta)

- uočljivost (primjetljivost odabrane tipografije)

- čitljivost (vizualna lakoća prepoznavanja teks-

ta)

- količina teksta

- korištenje tipografije u naglašavanju informacija (da li je tekst dominantan u prenošenju poruke).

Drugu skupinu čine tri kriterija koja se odnose na slogan, koji se pojavljuje kao lajt-motiv stranačke kampanje, a to su:

- orginalnost

- prepoznatljivost (da li se slogan lako povezuje sa strankom)

- jasnoća ( koliko je poruka jednoznačna ili dvosmislena).

Zatim slijede kriteriji vrednovanja za logotip, vizualni simbol koji bi trebao moći funkcionirati i samostalno, izvan konteksta jumbo-plakata. Logotip je kategorija čija je vizualnost unaprijed određena (osim ako nije došlo do redizajna), stoga se kriteriji vrednovanja odnose na:

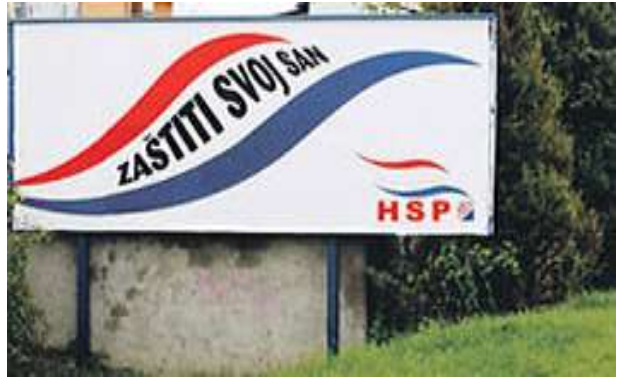

Slika 5. Plakat HSP-a

- uočljivost

- prepoznatljivost

- smještaj.

Četvrtu skupinu kriterija čine oni koji se odnose na fotografiju, a ona je prisutna kod tri od ukupno pet odabranih plakata:

- zanimljivost

- kompozicija (estetski raspored elemenata na plakatu)

- kontrast (vizualna kompatibilnost korištenih boja)

- atraktivnost.

Slijedeću skupinu čine elementi koji uvjetuju vizualnu uočljivost, a to su:

- uočljivost među ostalim plakatima

- uočljivost sa udaljenosti

- prvi dojam (prva reakcija)

- dugoročni dojam (ostavljanje učinka u svijesti)

- količina istaknutih informacija

- odabir pozadine plakata.

Posljednju skupinu kriterija čine elementi za koje bi se moglo reći da im je cilj postizanje psiholoških efekata:

- povezanost korištenih boja sa strankom

- vizualna prepoznatljivost stranke

- prisutnost emotivnog naboja

- poticanje emocionalne reakcije

- provokativnost 
- obraćanje ciljanoj skupini

- uvjerljivost odaslane poruke

- uvjerljivost osobe/a na plakatu (gdje je prisutna/tni) .

Kriterij koji nije stavljen $\mathrm{u}$ nijednu kategoriju, već je izdvojen je - ideja. Taj kriterij je izdvojen zbog svoje važnosti, jer je upravo ideja pokretač svakog dizajna, pa tako i grafičkog. Osnovni za-

\section{Obrada rezultata}

Prva skupina kriterija se odnosi na tipografiju. Tipografija je vrlo važan element, jer je često tekst nosioc poruke na plakatu. Na odabranim plakatima HSP-a i HDZ-a tekst je i jedini nositelj poruke, pa je zanimljivo vidjeti kako je ocjenjena njihova tipografija, koja je temeljni element plakata, $\mathrm{u}$ odnosu na druge stranke koje su uz tekst koristili i druge vizualne elemente.

Tablice i grafikoni prikazuju prosječnu ocjenu uspješnosti primjene profesionalnih kriterija važnih za kvalitetno oblikovanje tipografije. datak grafičkog dizajnera je da prezentira inovativno, a u isto vrijeme prepoznatljivo grafičko rješenje, te se ideja očituje u uspješnom i učinkovitom spajanju ova dva elementa. Grafički dizajn je oblik vizualne komunikacije, koji korištenjem teksta i slike prenosi neku poruku. Ta poruka može biti manje ili više vizualno atraktivno prenesena, a upravo tu do izražaja dolazi ideja.

Da bi se postigao bilo kakav učinak poruka mora biti percipirana. Da bi se privukla pažnja tipografija bi trebala sadržavati dozu inovativnosti. Kao što podaci pokazuju (tabela 1; grafikon 1), taj kriterij je na predizbornim plakatima slabo primijenjen, upotrebljeno je sve već viđeno, tako da se ocjene kreću od najniže 1,61 do najviše 2,61 . Najnižu ocjenu u inovativnosti tipografije dobio je HDZ, a upravo je na tom plakatu čitava poruka prikazana kroz tipografsko izražavanje.

\begin{tabular}{|l|c|c|c|c|c|}
\hline INOVATIVNOST & HDZ & SDP & HNS & HSS/HSLS & HSP \\
\hline Studenti II godine & 2,02 & 2,58 & 2,61 & 1,64 & 2,06 \\
\hline Studenti IV godine & 1,61 & 2,21 & 1,85 & 1,73 & 2,09 \\
\hline Uk. prosječna ocjena & 1,82 & 2,40 & 2,23 & 1,69 & 2,35 \\
\hline
\end{tabular}

Tabela 1.

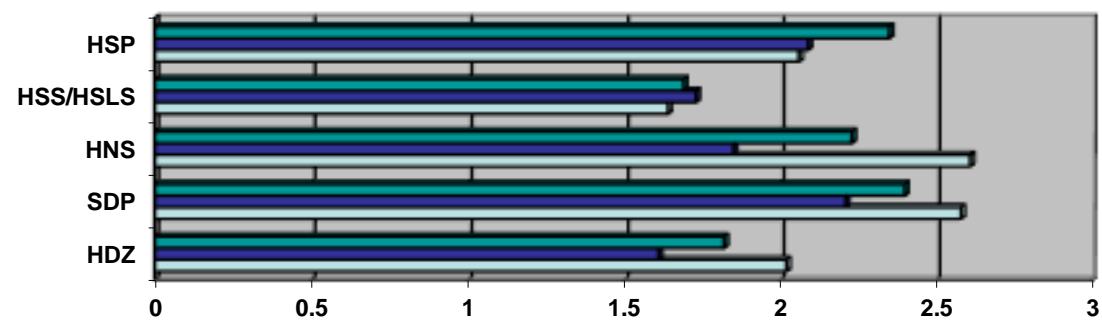

aUkupno
aStudenti IV
godine
aStudenti II godine

Grafikon 1.

Iako tipografija HDZ-ovog plakata nije inovativna, ona je uočljiva, pa je osnovni cilj zadovoljen - poruka je percipirana. U ovoj je kategoriji taj plakat ocjenjen znatno boljim ocjenama. Najbolje je ocjenjena tipografija korištena u SDPovom plakatu, koja nije dominantan nositelj po- ruke, za razliku od HSP-ovog plakata, gdje je tipografija primaran nositelj poruke, ali ipak je ocjenjena nedovoljno uočljivom (mada je gotovo jedini element na plakatu).

(Tabela 2; grafikon 2). 


\begin{tabular}{|l|c|c|c|c|c|}
\hline UOČLJIVOST & HDZ & SDP & HNS & HSS/HSLS & HSP \\
\hline Studenti II godine & 3,88 & 3,85 & 3,03 & 1,82 & 2,36 \\
\hline Studenti IV godine & 3,93 & 4,39 & 3,24 & 2,36 & 2,79 \\
\hline Uk. prosječna ocjena & 3,91 & 4,12 & 3,14 & 2,09 & 2,58 \\
\hline
\end{tabular}

Tabela 2.
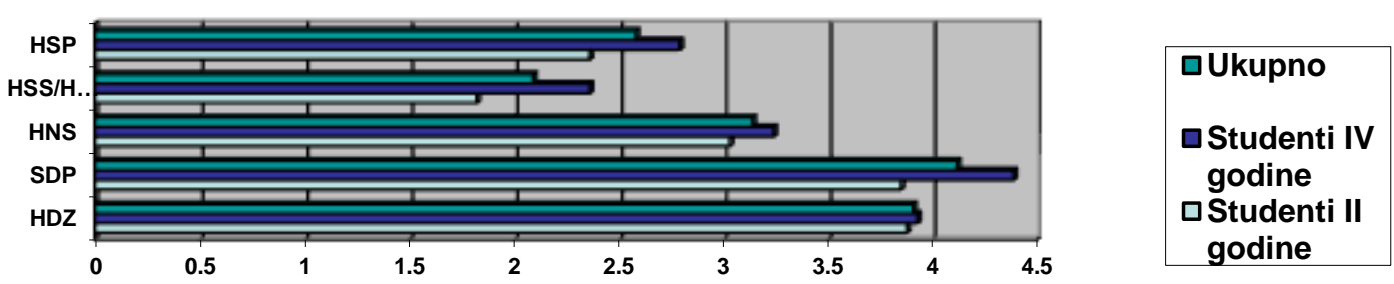

Grafikon 2.

Po kriteriju čitljivosti, najbolje je ocjenjen plakat SDP-a i HDZ-a, dok su ostala tri plakata dobila znatno niže ocjene. Najslabije ocjenjen plakat HSP-a ima tipografiju različitih veličina, koja nije smještena u ravnini, već je stješnjena između dvije obojane površine, dok je znatan dio plakat bijela, neiskorištena pozadina (tabela 3; grafikon 3)

\begin{tabular}{|l|c|c|c|c|c|}
\hline ČITLJIVOST & HDZ & SDP & HNS & HSS/HSLS & HSP \\
\hline Studenti II godine & 4,45 & 4,24 & 3,64 & 2,58 & 2,48 \\
\hline Studenti IV godine & 4,33 & 4,55 & 3,61 & 3,00 & 2,91 \\
\hline Uk. prosječna ocjena & 4,39 & 4,40 & 3,63 & 2,79 & 2,70 \\
\hline
\end{tabular}

Tabela 3.

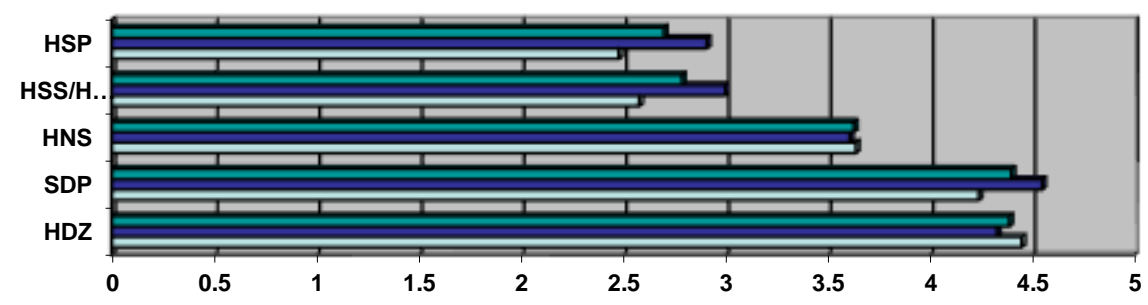

\begin{tabular}{l|} 
aUkupno \\
a Studenti IV \\
godine \\
aStudenti II \\
godine
\end{tabular}

Grafikon 3.

Da bi se zadovoljio prethodno navedeni kriterij, potrebno je koristiti optimalnu količinu teksta. Tekst ne može biti percipiran istom brzinom kao slika, za njegovo procesuiranje u svijesti potrebno je više vremena, stoga se s količinom teksta ne smije pretjerivati. Količina teksta najbolje je ocjenjena na SDP-ovom plakatu, gdje tekst nije jedini nositelj informacije (tabela 4; grafikon 4).

\begin{tabular}{|l|c|c|c|c|c|}
\hline KOLIČINA TEKSTA & HDZ & SDP & HNS & HSS/HSLS & HSP \\
\hline Studenti II godine & 2,94 & 3,52 & 2,94 & 2,48 & 2,24 \\
\hline Studenti IV godine & 2,75 & 3,91 & 3,39 & 3,03 & 3,03 \\
\hline Uk. prosječna ocjena & 2,85 & 3,72 & 3,17 & 2,76 & 2,77 \\
\hline
\end{tabular}

Tabela 4. 


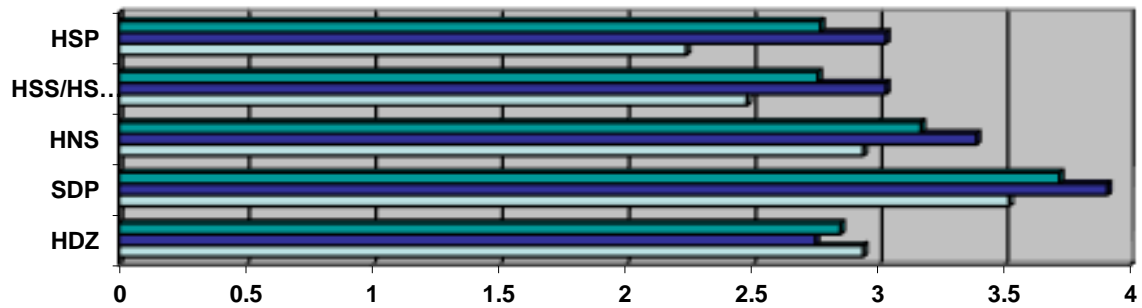

口Ukupno
$\square$ Studenti IV
godine
$\square$ Studenti II
godine

Grafikon 4

Isto tako, tipografija kao sredstvo naglašavanja informacija nabolje je ocjenjena na SDP-ovom plakatu, a zanimljivo je da je HDZ-ov plakat koji se koncepcijski potpuno razlikuje dobio slične ocjene. Najlošije je po ovom kriteriju, ocijenjen koalicijski plakat HSS/HSLS. (tabela 5; grafikon 5).

\begin{tabular}{|l|c|c|c|c|c|}
\hline $\begin{array}{l}\text { KORIŠTENJE } \\
\text { TIPOGRAFIJ } \\
\text { NAGLAŠAVANJU } \\
\text { INFORMACIJA }\end{array}$ & HDZ & SDP & HNS & HSS/HSLS & HSP \\
\hline Studenti II godine & 3,21 & 3,09 & 2,85 & 1,76 & 2,12 \\
\hline Studenti IV godine & 3,52 & 3,61 & 3,24 & 2,30 & 2,82 \\
\hline Uk. prosječna ocjena & 3,37 & 3,35 & 3,05 & 2,03 & 2,47 \\
\hline
\end{tabular}

Tabela 5 .
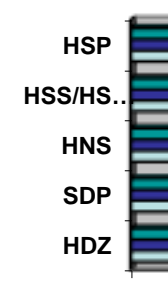

Grafikon 5

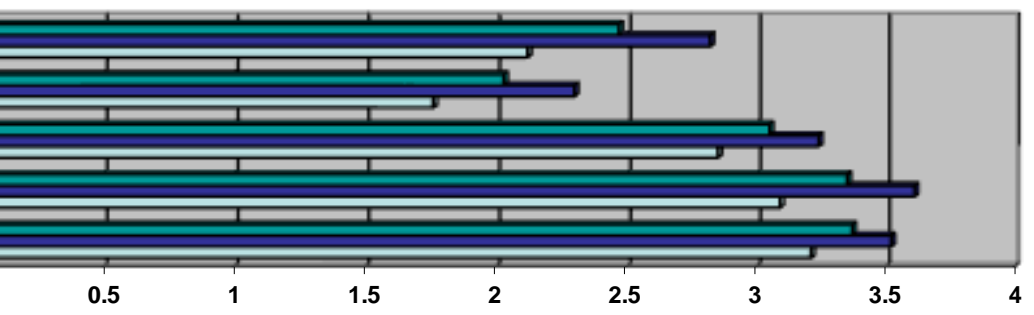

\begin{tabular}{|l|}
\hline 口Ukupno \\
aStudenti IV \\
godine \\
Studenti II \\
godine
\end{tabular}

Slijedeću skupinu kriterija čine elementi koji se odnose na slogan.

Slogan je kratka reklamna krilatica ili politička parola /7/. John Street /8/ ističe kako se „pakiranje politike" veže za ideju prema kojoj javnim predstavljanjem politike $u$ sve većoj mjeri upravljaju stranke i političari koji koriste usluge stručnjaka za pojedine medije. Političkim proizvodima se $u$ tom smislu može dati atraktivna „ambalaža" na sličan način kao ekonomskim proizvodima. Jedan dio ambalaže je zasigurno i slogan. Na tu misao nadovezuje se i Jacques Seguela, poznati voditelj dviju pobjedničkih kampanja Francoisa Mitteranda koji je rekao: "Za mene nema razlika između predsjednika i praška za pranje. Mislim da to nije uvredljivo za predsjednika, oba su robne marke, ličnosti od kojih treba učiniti zvijezdu."/9/ Jedna od osnovnih tehnika pakiranja politike su i "sound-biteovi“ - lako pamtljive, „udarne“ kratke poruke koji se opetovano ponavljaju. Kao sound-bites $u$ nekim situacijama mogu funkcionirati i sami nazivi stranaka /10/. HDZ-ova poruka svodi se na slogan „Biraj”, nije ni pozitivna ni negativna, konzumentu poruke ostavlja izbor, ali imperativni oblik slogana kao da nešto nameće, proslijeđuje naredbu. „Sound-bite“ koji zasigurno nema snagu poput slogana "Zna se!“. SDP koristi slogan „Ljudi su snaga“, što je u skladu sa logotipom SDP-tim i zapravo je poveznica cijele njihove kampanje. Koalicija HSS-HSLS koristi slogan „Budimo svoji“ koji se može različito protumačiti, stoga je poruka slogana prilično nejas- 
na i nije "sound-bite“ koji odmah ukazuje na tu koaliciju. HNS-ov slogan „Budućnost biramo sad“ je također izjava, parola koja se nadovezuje na njihov slogan sa prošlih parlamentarnih izbora "Gradimo budućnost zajedno!", iako je upitno koliko se i ta poruka uspjela održati kao sound-bite. Plakat HSP-a je baziran na sloganu, poruci, te bi snaga te poruke, kao jedinog ele- menta plakata, trebala biti ,jača“", od slogana ostalih stranaka koje su pažnju birača pokušale privuči i ostalim vizualnim elementima.

Tablice i grafikoni $(6-8)$ prikazuju prosječnu ocjenu uspješnosti primjene profesionalnih kriterija važnih za kvalitetno oblikovanje slogana i njegovo uklapanje u zajedničku grafičku cjelinu.

\begin{tabular}{|l|c|c|c|c|c|}
\hline ORGINALNOST & HDZ & SDP & HNS & HSS/HSLS & HSP \\
\hline Studenti II godine & 2,73 & 3,00 & 2,85 & 2,21 & 2,09 \\
\hline Studenti IV godine & 2,27 & 3,33 & 2,87 & 2,55 & 2,18 \\
\hline Uk. prosječna ocjena & 2,50 & 3,17 & 2,86 & 2,38 & 2,14 \\
\hline
\end{tabular}

Tabela 6

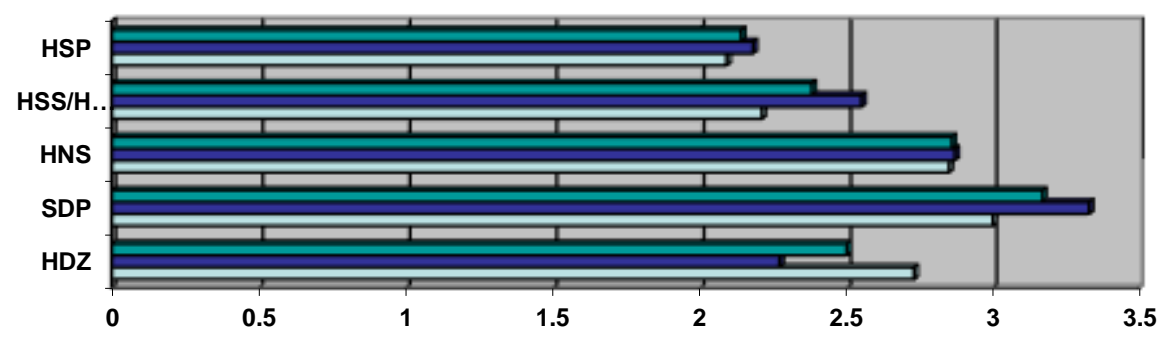

\begin{tabular}{|l|}
\hline 口Ukupno \\
口Studenti IV \\
godine \\
a Studenti II \\
godine
\end{tabular}

Grafikon 6.

\begin{tabular}{|l|c|c|c|c|c|}
\hline PREPOZNATLJIVOST & HDZ & SDP & HNS & HSS/HSLS & HSP \\
\hline Studenti II godine & 2,85 & 3,15 & 2,67 & 2,15 & 2,18 \\
\hline Studenti IV godine & 2,48 & 3,58 & 2,67 & 2,42 & 2,24 \\
\hline Uk. prosječna ocjena & 2,67 & 3,37 & 2,67 & 2,29 & 2,21 \\
\hline
\end{tabular}

Tabela 7.
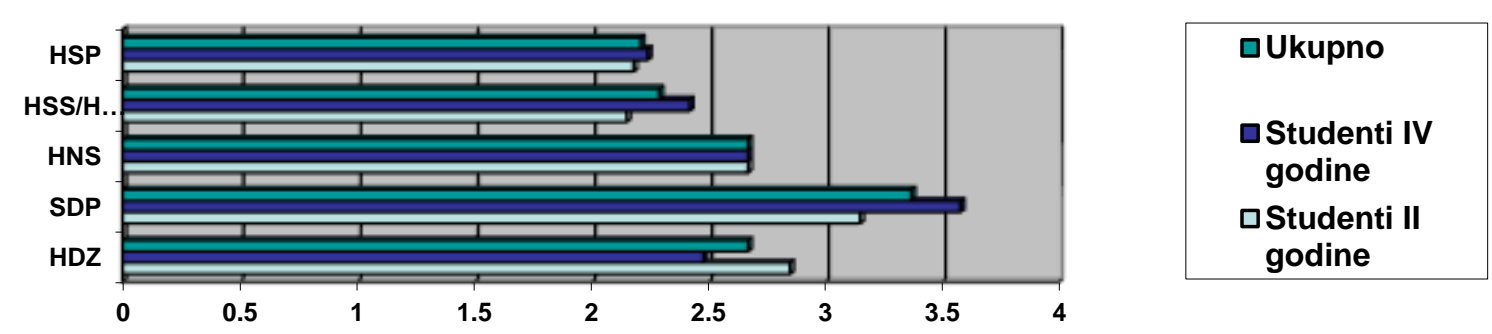

Grafikon 7.

\begin{tabular}{|l|c|c|c|c|c|}
\hline JASNOĆA & HDZ & SDP & HNS & HSS/HSLS & HSP \\
\hline Studenti II godine & 3,70 & 3,18 & 3,36 & 2,24 & 1,94 \\
\hline Studenti IV godine & 3,33 & 3,94 & 3,61 & 3,00 & 2,33 \\
\hline Uk.prosječna ocjena & 3,52 & 3,56 & 3,49 & 2,62 & 2,14 \\
\hline
\end{tabular}

Tabela 8. 


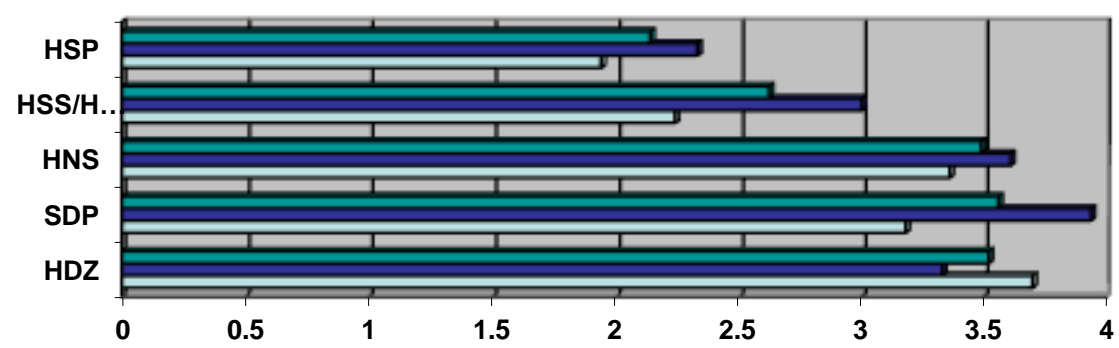

\begin{tabular}{|l|}
\hline aUkupno \\
aStudenti IV \\
godine \\
aStudenti II \\
godine \\
\hline
\end{tabular}

Grafikon 8.

Slijedeća tri kriterija odnose se na logotip. Riječ je izvedena iz grčkih riječi logos što znači riječ i týpos što znači lik, slika /11/.

Logotip je dio vizualnog identiteta, simbol koji bi trebao uspješno funkcionirati u svakom kontekstu, znači - biti prepoznatljiv i lako povezljiv s sadržajem kojemu pripada. Na svim plakatima korišteni su logotipovi koji nisu mijenjani ili su prošli minimalni redizajn, tako da prepoznatljivost nije ugrožena. Upravo je na logotipu prisutno najmanje dizajnerske kreativnosti, jer su korištena prijašnja vizualna rješenja. Stoga su za ocjenjivanje korišteni kriteriji koji nisu vezani za dizajn, već za smještaj logotipa. Ocjene uspješnosti logotipa navedene su u slijedećim tabelama i grafikonima $(9-11)$.

\begin{tabular}{|l|c|c|c|c|c|}
\hline UOČLJIVOST & HDZ & SDP & HNS & HSS/HSLS & HSP \\
\hline Studenti II godine & 2,79 & 3,70 & 3,39 & 3,12 & 2,88 \\
\hline Studenti IV godine & 2,27 & 3,67 & 3,85 & 3,33 & 3,21 \\
\hline Uk.prosječna ocjena & 2,53 & 3,69 & 3,62 & 3,26 & 3,05 \\
\hline
\end{tabular}

Tabela 9.
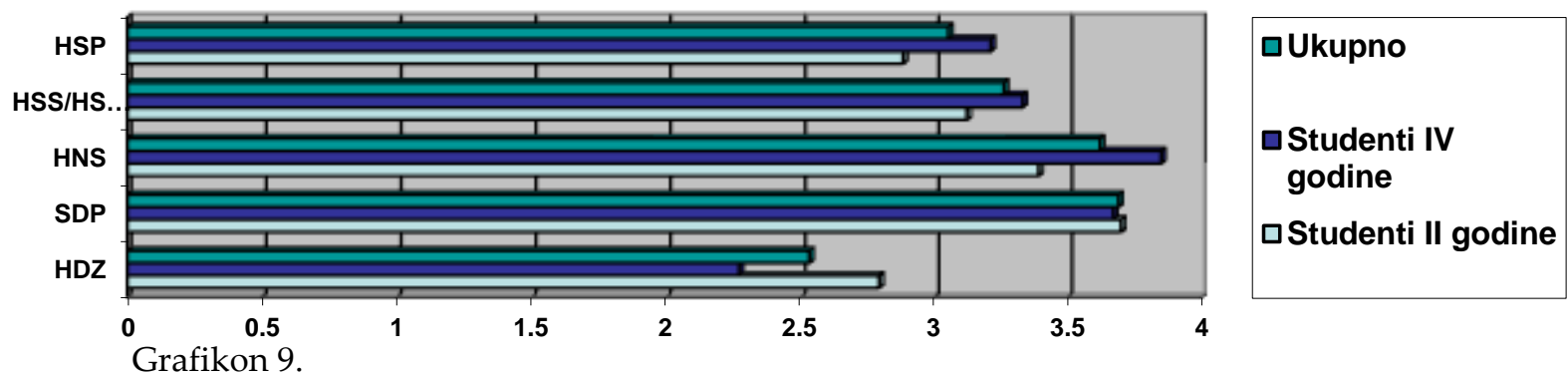

\begin{tabular}{|l|c|c|c|c|c|}
\hline PREPOZNATLJIVOST & HDZ & SDP & HNS & HSS/HSLS & HSP \\
\hline Studenti II godine & 3,76 & 4,09 & 3,51 & 3,06 & 2,79 \\
\hline Studenti IV godine & 3,67 & 4,06 & 3,91 & 3,55 & 3,21 \\
\hline Uk.prosječna ocjena & 3,72 & 4,08 & 3,71 & 3,31 & 3,06 \\
\hline
\end{tabular}

Tabela 10 


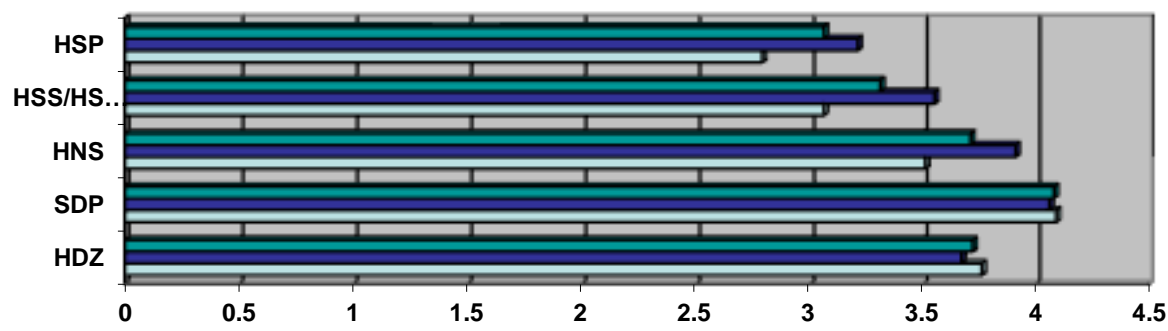

\begin{tabular}{|l|} 
uUkupno \\
a Studenti IV \\
godine \\
a Studenti II \\
godine
\end{tabular}

Grafikon 10.

\begin{tabular}{|l|c|c|c|c|c|}
\hline SMJEŠTAJ & HDZ & SDP & HNS & HSS/HSLS & HSP \\
\hline Studenti II godine & 2,42 & 3,42 & 4,30 & 3,12 & 2,63 \\
\hline Studenti IV godine & 2,27 & 3,70 & 3,50 & 3,21 & 3,18 \\
\hline Uk.prosječna ocjena & 2,35 & 3,56 & 3,90 & 3,17 & 2,91 \\
\hline
\end{tabular}

Tabela 11.

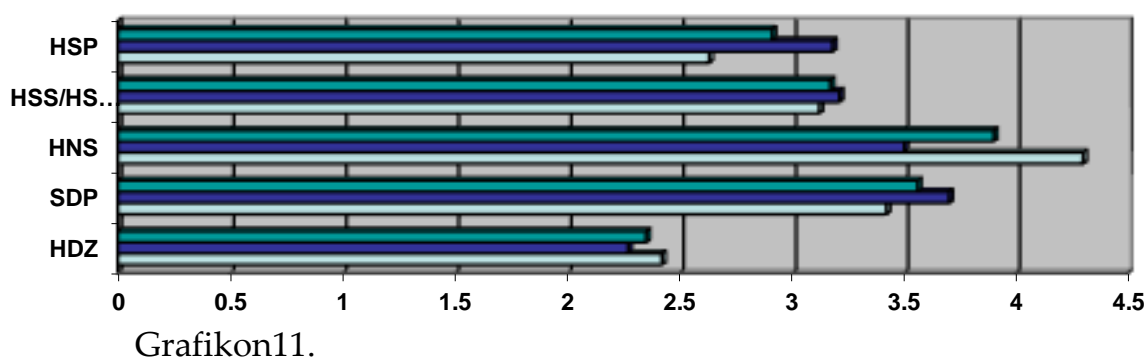

\section{口Ukupno}

口Studenti IV godine

口Studenti II godine
Narednu skupinu kriterija čine elementi vrednovanja koji se odnose na fotografiju. Od ukupno pet vrednovanih jumbo-plakata, njih tri se bazira na fotografiji. Sve tri fotografije prikazuju stranačke lidere, a ocijenjivani su s obzirom na karakteristike bitne za korištenje fotografije na jumbo plakatima. Kriteriji vrednovanja su zani- mljivost, kompozicija, kontrast i atraktivnost. Ocjene slijede $\mathrm{u}$ tabelama i grafikonima (12 15). U svim navedenim kriterijima, ocjene su za sve stranke podjednako loše (iznimka je SDP koji u pojedinim kriterijima doseže ocjenu 3), što upućuje da fotografije na plakatima nisu adekvatno korištene ili su krivo odabrane.

\begin{tabular}{|l|c|c|c|}
\hline ZANIMLJIVOST & SDP & HNS & HSS/HSLS \\
\hline Studenti II godine & 2,06 & 2,00 & 1,40 \\
\hline Studenti IV godine & 2,33 & 1,84 & 2,03 \\
\hline Uk.prosječna ocjena & 2,20 & 1,92 & 1,72 \\
\hline
\end{tabular}

Tabela 12.

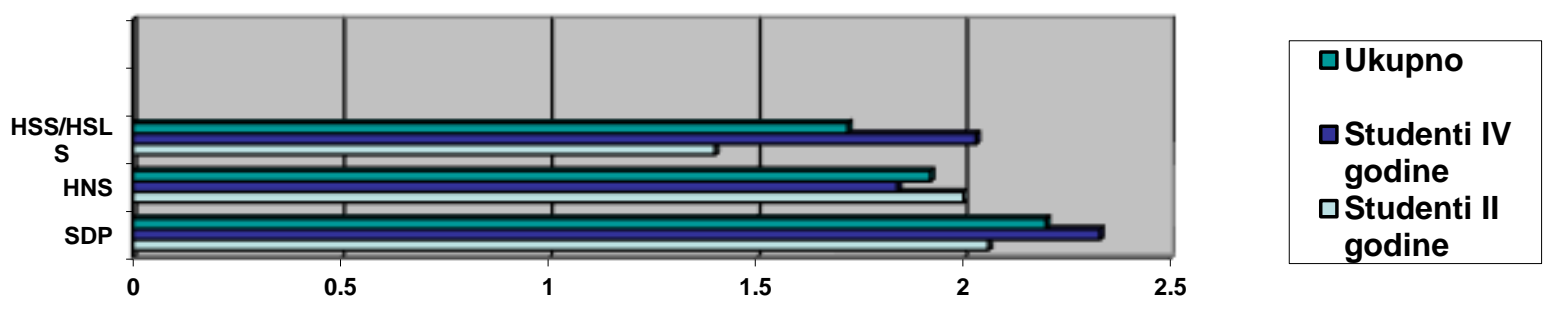

Grafikon 12. 


\begin{tabular}{|l|c|c|c|}
\hline KOMPOZICIJA & SDP & HNS & HSS/HSLS \\
\hline Studenti II godine & 3,00 & 2,42 & 2,06 \\
\hline Studenti IV godine & 3,30 & 2,81 & 2,55 \\
\hline Uk.prosječna ocjena & 3,15 & 2,62 & 2,31 \\
\hline
\end{tabular}

Tabela 13.

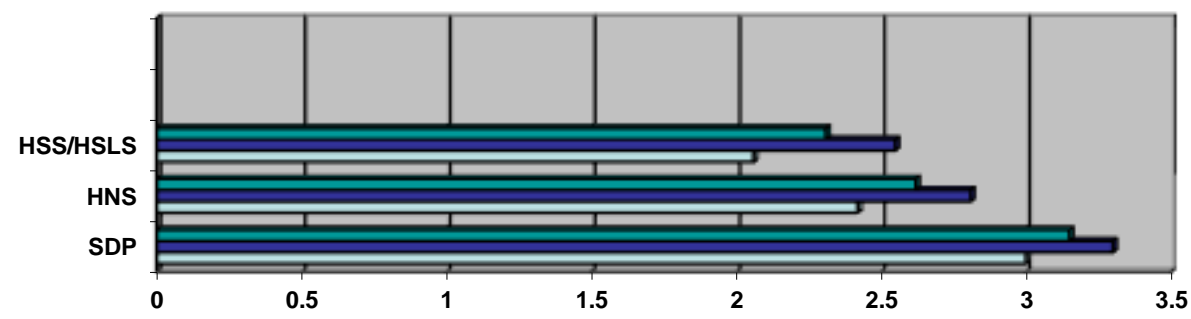

\begin{tabular}{|l|}
\hline 口Ukupno \\
घStudenti IV \\
godine \\
QStudenti II \\
godine \\
\hline
\end{tabular}

Grafikon 13.

\begin{tabular}{|l|c|c|c|}
\hline KONTRAST & SDP & HNS & HSS/HSLS \\
\hline Studenti II godine & 2,45 & 2,39 & 2,00 \\
\hline Studenti IV godine & 3,09 & 2,63 & 2,33 \\
\hline Uk.prosječna ocjena & 2,77 & 2,51 & 2,17 \\
\hline
\end{tabular}

Tabela 14.

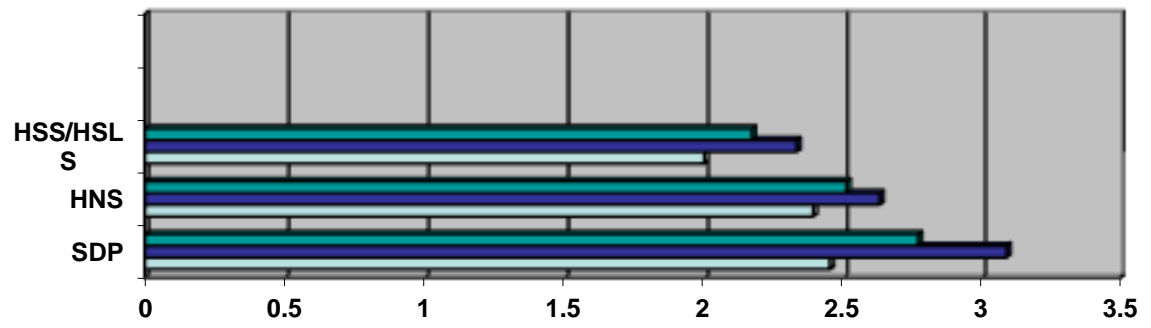

\begin{tabular}{|l|}
\hline aUkupno \\
aStudenti IV \\
godine \\
Studenti II \\
godine \\
\hline
\end{tabular}

Grafikon 14.

\begin{tabular}{|l|c|c|c|}
\hline ATRAKTIVNOST & SDP & HNS & HSS/HSLS \\
\hline Studenti II godine & 2,36 & 2,09 & 1,75 \\
\hline Studenti IV godine & 2,48 & 2,33 & 2,05 \\
\hline Uk.prosječna ocjena & 2,42 & 2,21 & 1,9 \\
\hline
\end{tabular}

Tabela 15

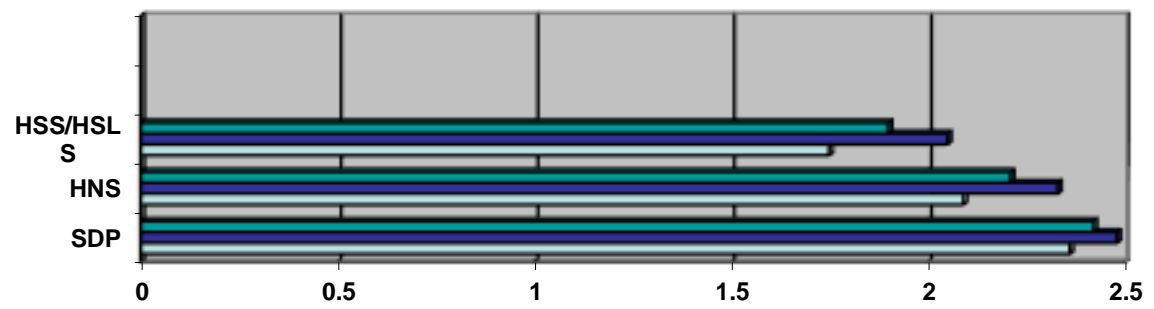

\begin{tabular}{|l|}
\hline 口Ukupno \\
QStudenti IV \\
godine \\
Studenti II \\
godine \\
\hline
\end{tabular}




\section{Grafikon 15.}

Da bi plakat postigao svoju svrhu, on mora biti uočljiv. Impozantne dimenzije jumbo-plakata nisu dovoljne da bi se postigao taj cilj, potrebno je pronaći još neke faktore da bi se uspjelo izdvojiti iz mase informacija. Jumbo - plakat mora biti uočljiv među drugim plakatima. Jumboplakati stoje na samostalnom postolju ili na postoljima poredanim jedan do drugog i upravo tu je važno postići skretanje pozornosti na željenu poruku. Isto tako, on mora biti uočljiv sa udaljenosti, a da bi to bio, ne smije imati suviše detalja. Kada dođe do uočavanja stvara se prvi dojam, koji može biti pozitivan, negativan ili indiferentan, a također može doći do stvaranja dugoročnog dojma, koji rezultira stvaranjem nekog učinka u našoj svijesti. Da bi se ostvarili prethodno navedeni elementi, potrebno je odrediti optimalnu količinu informacija koje će biti na plakatu i odabrati prikladnu pozadinu koja neće dovoditi do interferencije percepcije informacija. Ocjene navedenih elemenata navedene su u slijedećim tabelama.

\begin{tabular}{|l|c|c|c|c|c|}
\hline $\begin{array}{l}\text { UOČLJIVOST MEĐU } \\
\text { OSTALIM PLAKATIMA }\end{array}$ & HDZ & SDP & HNS & HSS/HSLS & HSP \\
\hline Studenti II godine & 3,40 & 3,09 & 2,12 & 2,51 & 2,67 \\
\hline Studenti IV godine & 3,40 & 3,33 & 2,79 & 2,61 & 2,50 \\
\hline Uk.prosječna ocjena & 3,40 & 3,21 & 2,46 & 2,56 & 2,59 \\
\hline
\end{tabular}

Tabela 16

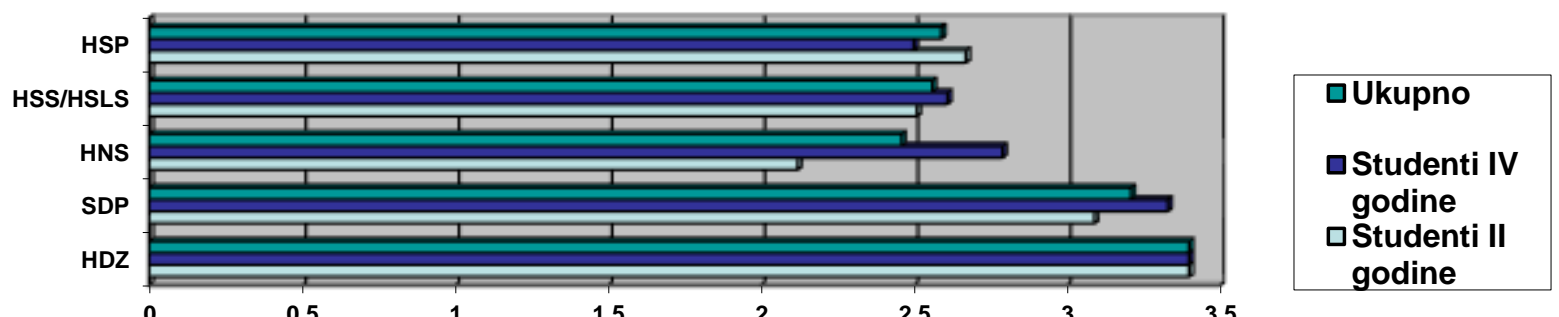

Grafikon 16.

\begin{tabular}{|l|c|c|c|c|c|}
\hline $\begin{array}{l}\text { UOČLJIVOST SA } \\
\text { UDALJENOSTI }\end{array}$ & HDZ & SDP & HNS & HSS/HSLS & HSP \\
\hline Studenti II godine & 4,09 & 3,60 & 2,52 & 2,03 & 3,20 \\
\hline Studenti IV godine & 3,60 & 3,80 & 3,15 & 2,70 & 3,00 \\
\hline Uk.prosječna ocjena & 3,85 & 3,70 & 2,84 & 2,37 & 3,10 \\
\hline
\end{tabular}

Tabela 17.

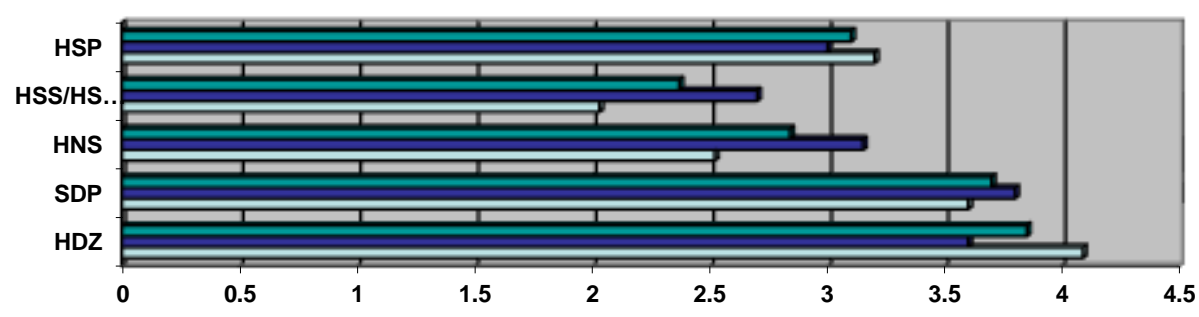

\begin{tabular}{|l|}
\hline 口Ukupno \\
aStudenti IV \\
godine \\
Studenti II \\
godine \\
\hline
\end{tabular}

Grafikon 17. 
Mario Plenković, Daria Mustić, Slobodan Hadžić: METODOLOŠKI OKVIR ZA KOMUNIKOLOŠKU PROCJENU USPJEŠNOSTI VIZUALNIH KRITERIJA PARLAMENTARNIH STRANAKA U IZBORNIM KAMPANJAMA

\begin{tabular}{|l|c|c|c|c|c|}
\hline PRVI DOJAM & HDZ & SDP & HNS & HSS/HSLS & HSP \\
\hline Studenti II godine & 2,58 & 2,55 & 2,33 & 1,67 & 1,79 \\
\hline Studenti IV godine & 2,15 & 3,27 & 2,54 & 2,24 & 1,72 \\
\hline Uk.prosječna ocjena & 2,37 & 3,13 & 2,44 & 1,96 & 1,76 \\
\hline
\end{tabular}

Tabela 18.

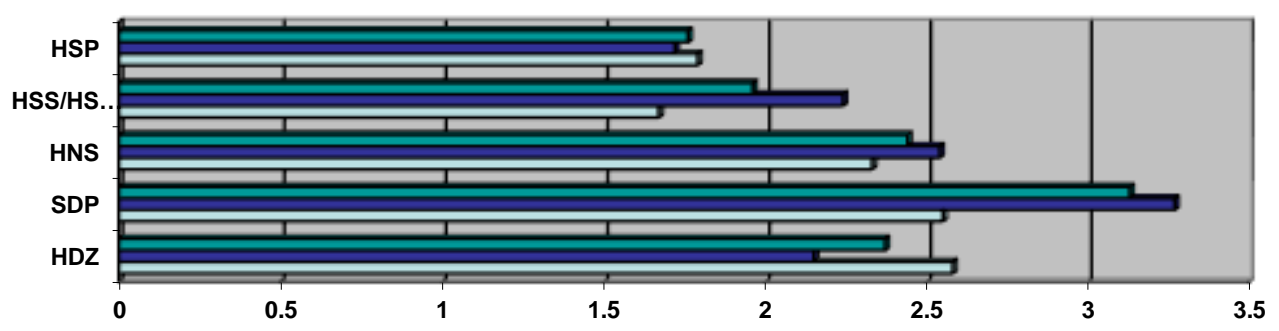

口Ukupno

口Studenti IV

godine

$\square$ Studenti II

godine

Grafikon 18.

\begin{tabular}{|l|c|c|c|c|c|}
\hline $\begin{array}{l}\text { DUGOROČNI } \\
\text { DOJAM }\end{array}$ & HDZ & SDP & HNS & HSS/HSLS & HSP \\
\hline Studenti II godine & 3,30 & 2,88 & 2,42 & 2,12 & 1,97 \\
\hline Studenti IV godine & 3,39 & 3,36 & 2,48 & 2,30 & 2,36 \\
\hline Ukupno & 3,35 & 3,12 & 2,45 & 2,21 & 2,17 \\
\hline
\end{tabular}

Tabela 19.

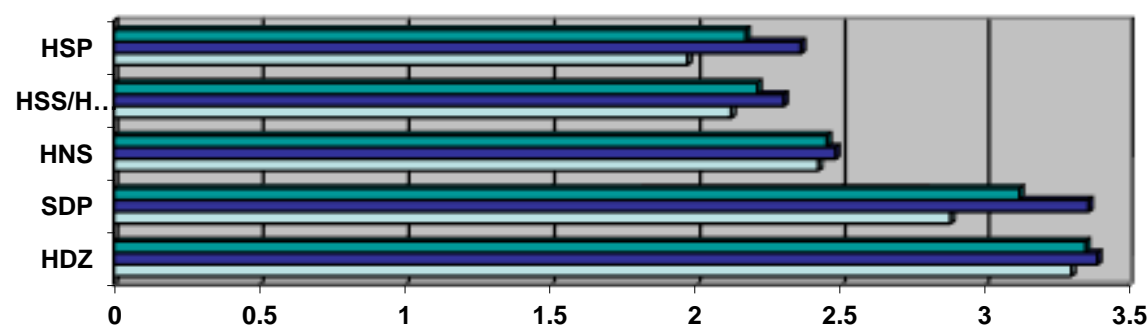

\begin{tabular}{|l|}
\hline Ukupno \\
atudenti IV \\
godine \\
a Studenti II \\
godine \\
\hline
\end{tabular}

Grafikon 19.

\begin{tabular}{|l|c|c|c|c|c|}
\hline $\begin{array}{l}\text { KOLIČINA } \\
\text { ISTAKNUTIH } \\
\text { INFORMACIJA }\end{array}$ & HDZ & SDP & HNS & HSS/HSLS & HSP \\
\hline Studenti II godine & 3,36 & 2,63 & 2,88 & 1,97 & 1,97 \\
\hline Studenti IV godine & 2,60 & 3,36 & 2,30 & 2,67 & 2,18 \\
\hline Ukupno & 2,98 & 3,00 & 2,59 & 2,32 & 2,08 \\
\hline
\end{tabular}

Tabela 20. 


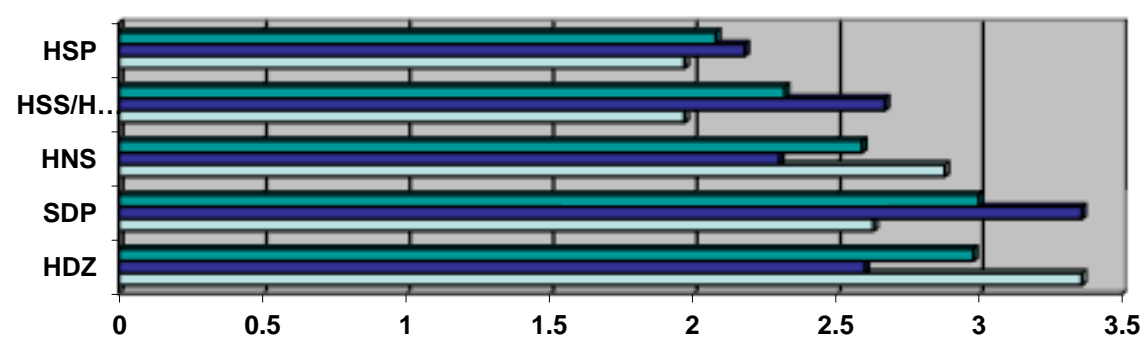

\begin{tabular}{|l|}
\hline uUkupno \\
aStudenti IV \\
godine \\
QStudenti II \\
godine \\
\hline
\end{tabular}

Grafikon 20.

\begin{tabular}{|l|c|c|c|c|c|}
\hline $\begin{array}{l}\text { ODABIR } \\
\text { POZADINE }\end{array}$ & HDZ & SDP & HNS & HSS/HSLS & HSP \\
\hline Studenti II godine & 3,36 & 3,33 & 2,79 & 1,81 & 1,81 \\
\hline Studenti IV godine & 2,30 & 3,24 & 2,55 & 2,33 & 1,42 \\
\hline Ukupno & 2,83 & 3,29 & 2,67 & 2,07 & 1,62 \\
\hline
\end{tabular}

Tabela 21.

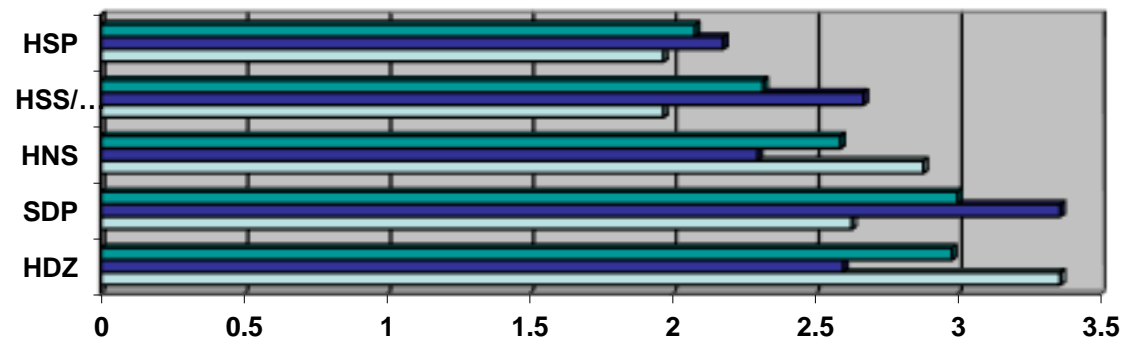

\begin{tabular}{|l|}
\hline ukupno \\
QStudenti IV \\
godine \\
¿Studenti II \\
godine \\
\hline
\end{tabular}

Grafikon 21.

\begin{tabular}{|l|c|c|c|c|c|}
\hline $\begin{array}{l}\text { POVEZANOST } \\
\text { KORIŠTENIH BOJA } \\
\text { SA STRANKOM }\end{array}$ & HDZ & SDP & HNS & HSS/HSLS & HSP \\
\hline Studenti II godine & 4,03 & 4,24 & 3,09 & 2,21 & 2,42 \\
\hline Studenti IV godine & 3,76 & 4,33 & 3,55 & 2,70 & 2,81 \\
\hline Ukupno & 3,90 & 4,29 & 3,32 & 2,46 & 2,62 \\
\hline
\end{tabular}

Tabela 22.

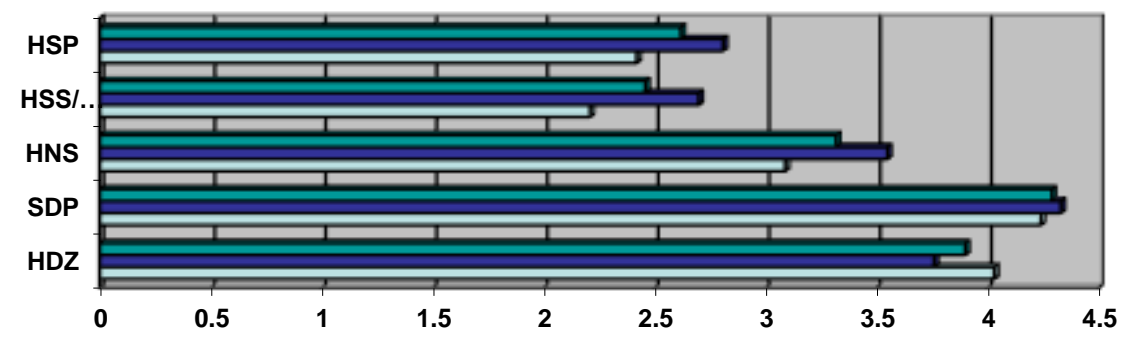

घUkupno
a Studenti IV
godine
a Studenti II
godine

Grafikon 22. 


\begin{tabular}{|l|c|c|c|}
\hline $\begin{array}{l}\text { UVJERLJIVOST OSOBE } \\
\text { NA PLAKATU }\end{array}$ & SDP & HNS & HSS/HSLS \\
\hline Studenti II godine & 2,39 & 2,33 & 1,78 \\
\hline Studenti IV godine & 2,88 & 2,76 & 2,27 \\
\hline Ukupno & 2,64 & 2,55 & 2,03 \\
\hline
\end{tabular}

Tabela 23.

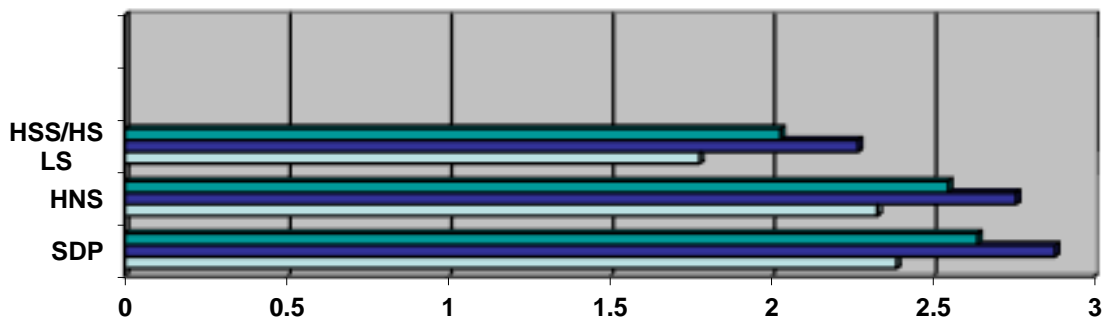

\section{口Ukupno}

$\square$ Studenti IV godine $\square$ Studenti II godine

Grafikon 23.

\begin{tabular}{|l|c|c|c|c|c|}
\hline $\begin{array}{l}\text { UVJERLJIVOST } \\
\text { ODASLANE PORUKE }\end{array}$ & HDZ & SDP & HNS & HSS/HSLS & HSP \\
\hline Studenti II godine & 2,33 & 2,70 & 2,48 & 1,85 & 1,81 \\
\hline Studenti IV godine & 2,33 & 3,09 & 2,88 & 2,27 & 1,88 \\
\hline Ukupno & 2,33 & 2,90 & 2,68 & 2,06 & 1,85 \\
\hline
\end{tabular}

Tabela 24.

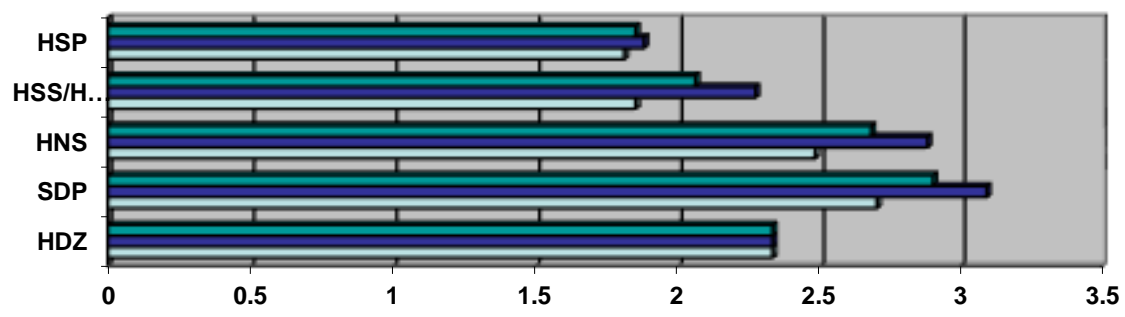

\section{口Ukupno}

$\square$ Studenti IV godine

$\square$ Studenti II godine

Grafikon 24.

\begin{tabular}{|l|c|c|c|c|c|}
\hline $\begin{array}{l}\text { OBRAĆANJE } \\
\text { CILJANOJ SKUPINI }\end{array}$ & HDZ & SDP & HNS & HSS/HSLS & HSP \\
\hline Studenti II godine & 3,42 & 2,73 & 3,33 & 2,70 & 1,67 \\
\hline Studenti IV godine & 3,12 & 3,06 & 2,55 & 2,79 & 1,85 \\
\hline Ukupno & 3,27 & 2,90 & 2,94 & 2,75 & 1,76 \\
\hline
\end{tabular}

Tabela 25. 


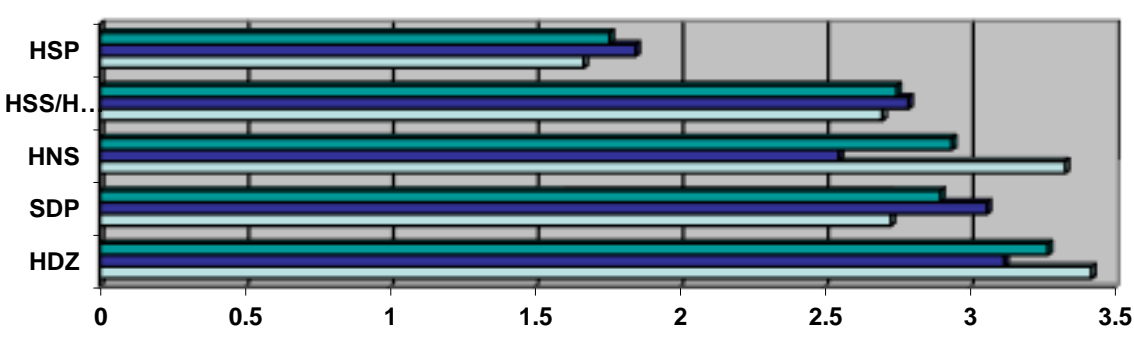

\section{口Ukupno \\ 口Studenti IV godine \\ 口Studenti II godine}

Grafikon 25.

\begin{tabular}{|l|c|c|c|c|c|}
\hline PROVOKATIVNOST & HDZ & SDP & HNS & HSS/HSLS & HSP \\
\hline Studenti II godine & 3,70 & 2,09 & 1,70 & 1,40 & 1,36 \\
\hline Studenti IV godine & 3,45 & 2,03 & 1,73 & 1,94 & 1,52 \\
\hline Ukupno & 3,58 & 2,06 & 1,72 & 1,67 & 1,44 \\
\hline
\end{tabular}

Tabela 26.

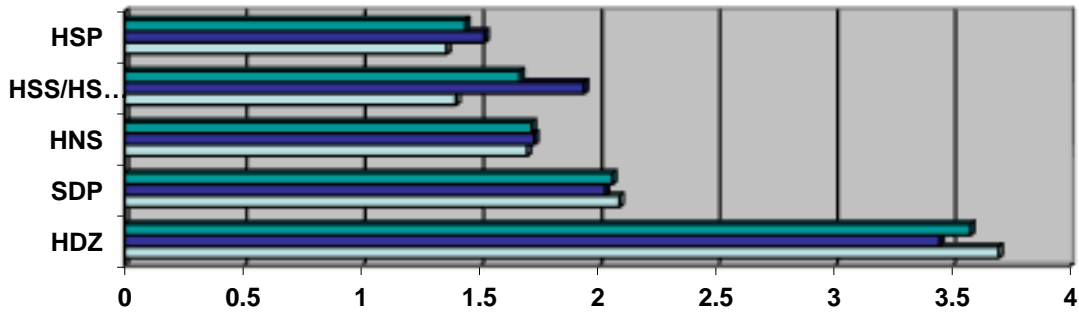

\section{口Ukupno}

口Studenti IV godine

口Studenti II godine

Grafikon 26.

„Značaj emocija u propagandnoj aktivnosti je ogroman. Riječ je o aspektu ljudske psihe koji je najosjetljiviji i najpodatniji za djelovanje. Svaki doživljaj i svaka reakcija nužno ima i svoj emocionalni aspekt. Uostalom, i sam stav, koji je bez daljnjega osnovni objekt propagandnog djelovanja , brojni autori određuju kao svojevrsnu emocionalnu reakciju. Izazivanjem određenih emocija stvaraju se pretpostavke za lakše djelovanje propagandnog sadržaja, smanjuje se eventualni otpor i smanjuje kritičnost. Stoga postoje brojne tehnike i mehanizmi usmjereni na emocionalnu komponentu stava radi postizanja bržega i neposrednijega propagandnog efekta. ,"/12/
Da bi uopće došlo do emocionalne reakcije, potrebno je stvoriti emocionalni naboj koji će rezultirati reakcijom. Da bi se to postigle koriste se emocionalno ,jake“ riječi i fraze. Koriste se konotativna značenja riječi i na taj način se nabijaju emocijama i prejudiciraju pozitivno ili negativno značenje.

\begin{tabular}{|l|c|c|c|c|c|}
\hline $\begin{array}{l}\text { POTICANJE } \\
\text { EMOCIONALNE } \\
\text { REAKCIJE }\end{array}$ & HDZ & SDP & HNS & HSS/HSLS & HSP \\
\hline Studenti II godine & 2,33 & 2,73 & 2,70 & 1,67 & 1,67 \\
\hline Studenti IV godine & 2,52 & 2,61 & 2,52 & 2,39 & 1,58 \\
\hline Ukupno & 2,43 & 2,67 & 2,61 & 2,03 & 1,63 \\
\hline
\end{tabular}

Tabela 27. 


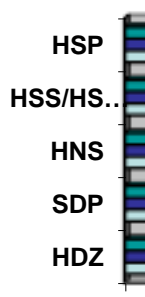

Grafikon 27.
Izabrani politički plakati u kategoriji poticanja emocionalne reakcije nisu ocijenjeni visokim ocjenama, što znači da odabrani elementi nisu uspjeli osigurati tu funkciju. Zanimljivo je da je
HSP dobio najlošije ocjene, iako je njihov plakat ciljao upravo na poticanje emocionalne reakcije (Zaštiti svoj san! - jako konotativno značenje). Isti je slučaj sa HDZ-ovim plakatom.

\begin{tabular}{|l|c|c|c|c|c|}
\hline $\begin{array}{l}\text { PRISUTNOST } \\
\text { EMOTIVNOG } \\
\text { NABOJA }\end{array}$ & HDZ & SDP & HNS & HSS/HSLS & HSP \\
\hline Studenti II godine & 2,15 & 2,48 & 2,27 & 1,58 & 1,58 \\
\hline Studenti IV godine & 2,03 & 2,94 & 2,36 & 2,21 & 1,73 \\
\hline Ukupno & 2,09 & 2,71 & 2,32 & 1,90 & 1,66 \\
\hline
\end{tabular}

Tabela 28.

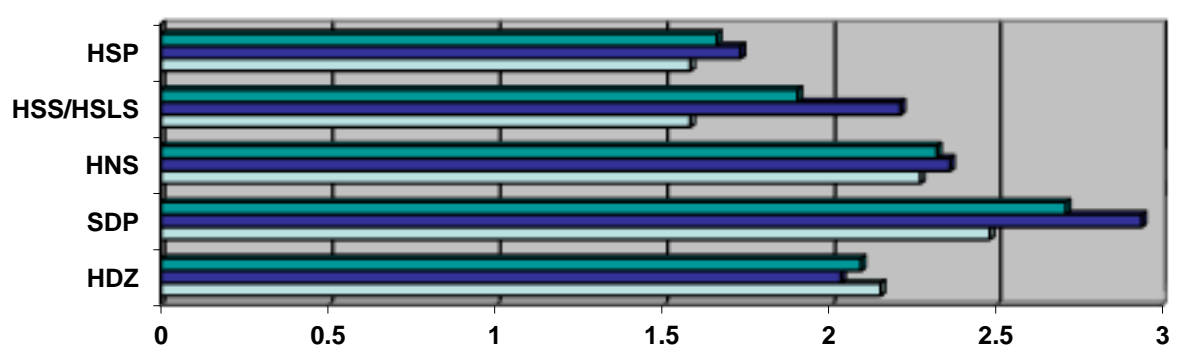

Grafikon 28.

Slaba ocjena poticanja emocionalne reakcije je izravna posljedica slabe prisutnosti emotivnog naboja. Opet je najslabiji HSP (čiji plakat u ovoj kategoriji nije dobio prolaznu ocjenu), HSS/HSLS (prolaznu ocjenu su mu dali studenti IV godine) i HDZ( jedva prolazna ocjena). 


\begin{tabular}{|l|c|c|c|c|c|}
\hline $\begin{array}{l}\text { VIZUALNA } \\
\text { PREPOZNATLJIVOST } \\
\text { STRANKE }\end{array}$ & HDZ & SDP & HNS & HSS/HSLS & HSP \\
\hline Studenti II godine & 3,36 & 3,36 & 3,00 & 2,21 & 2,09 \\
\hline Studenti IV godine & 2,73 & 3,82 & 2,97 & 2,52 & 2,39 \\
\hline Ukupno & 3,05 & 3,59 & 2,99 & 2,37 & 2,24 \\
\hline
\end{tabular}

Tabela 29.

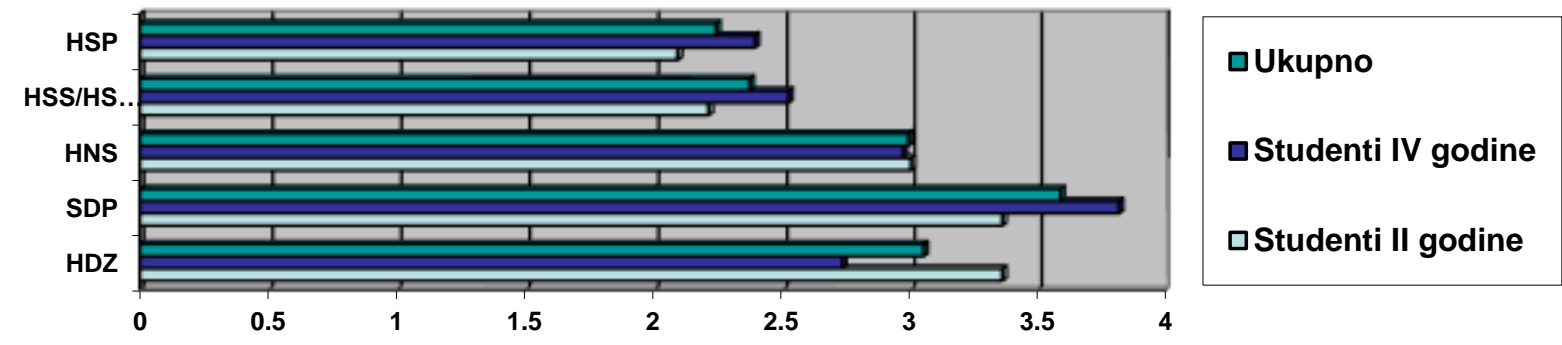

Grafikon 29.

Posljednji kriterij, koji smo izdvojili kao najvažniji, ocijenjen je prosječnim ocjenama u rasponu od 1,36 do 3,03. Najlošije je ocijenjen plakat HSPa, ali je prisutna razlika u ocjeni između studenata II i IV godine. Stariji studenti plakatu nisu dali prolaznu ocijenu, dok su mu mlađi studenti dali čvrstu dvojku. Isti je slučaj sa plakatom HDZ-a koji su stariji studenti ocijenili lošijim od mlađih kolega, koji su orginalnost HDZ-ova plakata ocijenili najvišom ocjenom (iako još uvijek prosječnom trojkom).

\begin{tabular}{|l|l|l|l|l|l|}
\hline IDEJA & \multicolumn{1}{|c|}{ HDZ } & \multicolumn{1}{c|}{ SDP } & HNS & HSS/HSLS & HSP \\
\hline Studenti II godine & 3,03 & 2,73 & 2,58 & 1,70 & 2,33 \\
\hline Studenti IV godine & 2,12 & 2,91 & 2,21 & 2,45 & 1,36 \\
\hline Ukupno & 2,58 & 2,82 & 2,40 & 2,08 & 1,85 \\
\hline
\end{tabular}

Tabela 30.
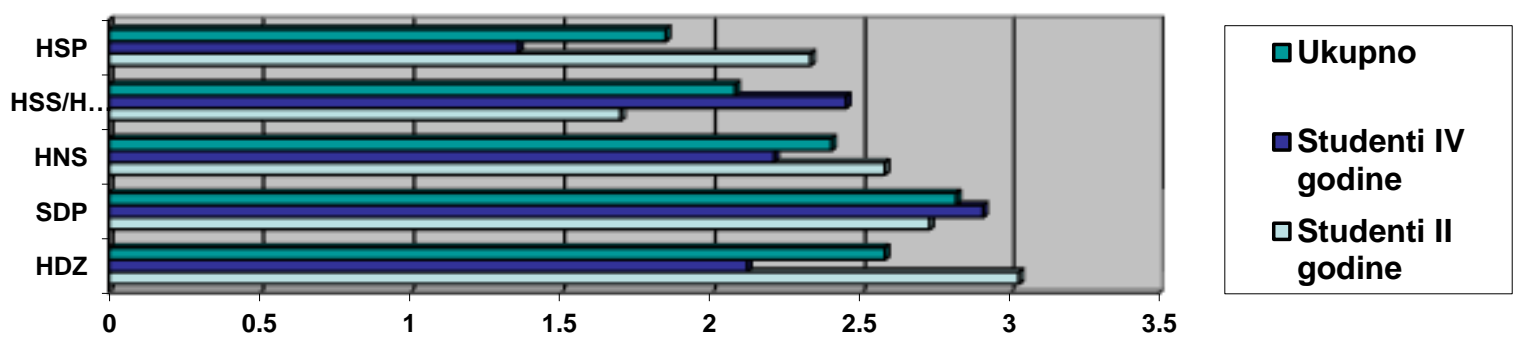

Grafikon 30.

Na kraju ankete, od studenata je zatraženo da procijene tko će pobijediti na parlamentarnim izborima, uzimajući u obzir samo procjenjivane jumbo-plakate, tj. da na temelju viđenih plakata procijene koja je stranka bila najuspješnija $u$ prenošenju svoje promidžbene poruke. 

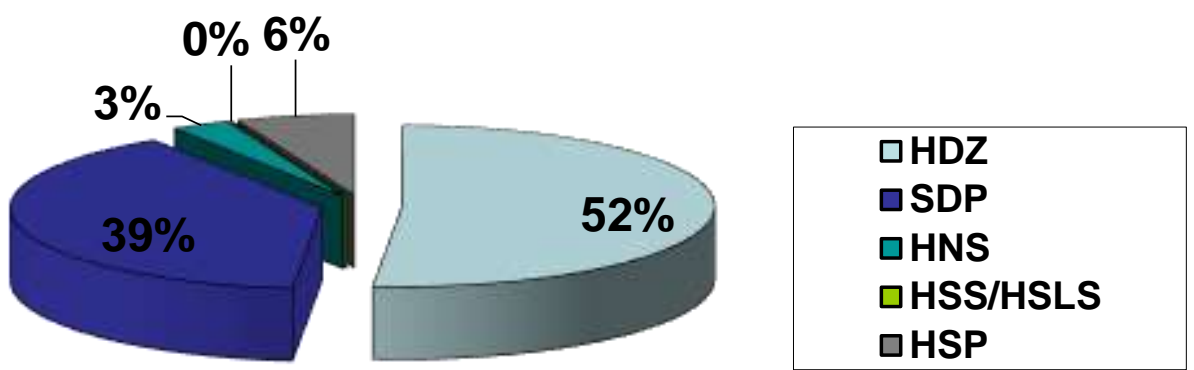

Grafikon 31.

Grafikon 31. prikazuje procjenu studenata II godine. Nadpolovičnu prednost dali su HDZ-u, slijedeći je SDP sa $39 \%$ glasova, dok se ostalim strankama daju male šanse.

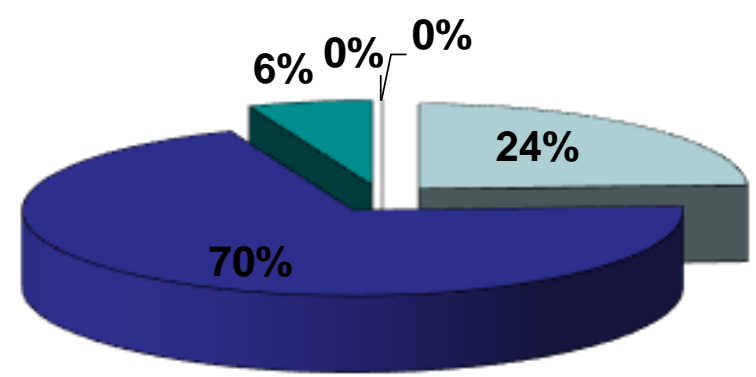

\begin{tabular}{|l|}
\hline 口HDZ \\
口SDP \\
口HNS \\
口HSS/HSLS \\
पHSP \\
\hline
\end{tabular}

Grafikon 32.

Grafikon 32. prikazuje procjenu studenata IV godine. Dobiveni rezultati su pokazali značajnu razliku između procjene studenata II i IV godine. Stariji su studenti značajnu prednost dali SDP-u, što je u skladu sa ocjenama koje su studenti davali po pojedinim kriterijima. Tako je
HDZ dobivao više ocjene kod studenata II godine, a stariji su studenti stupanj primjene profesionalnih grafičkih kriterija ocijenili višim kod SDP-ovog plakata. Posljednji grafikon prikazuje zbirnu procjenu studenata II i IV godine.

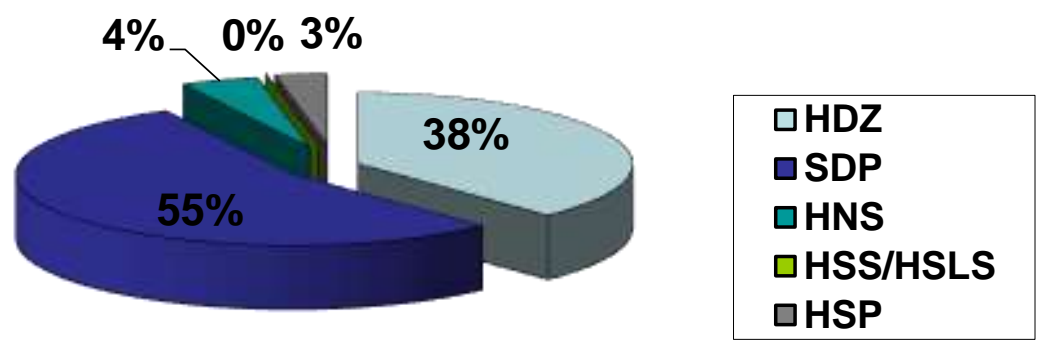

Grafikon 33. 


\section{Zaključak}

Istraživanje je pokazalo da na odabranim plakatima, po procjeni ispitanika, profesionalni grafički kriteriji nisu u dovoljnoj mjeri primjenjivani. Uočena je i razlika između dvije skupine ispitanika. Studenti II godine smatraju da je profesionalnije izrađen plakat HDZ-a, dok stariji studenti znakovitu prednost daju plakatu SDP-a. U istraživanju nisu ispitivani razlozi te razlike. Procjena studenata o izbornom pobjedniku izvedena je samo na temelju viđenih plakata, tj. samo na jednom specifičnom dijelu medijske komunikacije. Drugi mediji nisu uzeti u obzir, kao ni drugi oblici promidžbe poput skupova, letaka, koncerata i sl. Istraživanje je moguće proširiti tako da se u uzorak uključi šira populacija, s ciljem istraživanja percepcije profesionalnih grafičkih kriterija od strane neprofesionalaca.

\section{Bilješke}

/1/ M.Plenković, S. Hadžić, M. Kučiš: Dijalektika medijske moći i izborno građansko ponašanje (Hrvatski parlamentarni izbori 2003); Informatologia, 39,2006, 1, 1-21, str. 3

/2/ Izvor: Agencija Europlakat

/3/ navedeno prema www. outdoorakzent.hr/proizvodi_billboard_plakat.htm
/4/Ibidem /2/

/5/ Izvor: Agencija Promocija plus, Media monitoring; Izbori za Hrvatski sabor 2007., Monitoring ulaganja u oglašavanja političkih stranaka i kandidata u izbornoj kampanji za Hrvatski sabor 2007; naručitelj: Transparency International Hrvatska i GONG

/6/ Ibidem /1/, str. 17.

/7/ V. Anić: Rječnik hrvatskog jezika, Novi liber; Zagreb, 1991.

/8/ J. Street: Masovni mediji, politika i demokracija, Politička misao, Zagreb, 2003.

/9/ S. Vrcan, B. Buklijaš, D. Lalić, S. Kunac, N. Bulat, D. Štrelov: Pakiranje vlasti, Alineja, Zagreb, 1999.

/10/ Ibid /8/

/11/ Ibid /7/

/12/ I.Šiber: Politička propaganda i politički marketing, Alineja, Zagreb, 1992., str. 31

Literatura

1. Cutlip, S. ; Center, A., Broom, G. : Odnosi s javnošću, Mate, Zagreb, 2003.

2. Edelman, M.: Konstrukcija političkog spektakla, Politička kultura, Zagreb, 2003.

3. Jantol T.: Politička javnost, Birotisak, Zagreb, 2004.

4. Plenković, M.: Komunikologija masovnih medija, Barbat, Zagreb, 1993.

5. Šiber, I.: Politički marketing, Politička kultura, 2003.

\title{
COMMUNICATION ANALYSIS OF VISUAL CRITERIA FOR EVALUATION OF SUCCESS OF PARLIAMENTARY PARTIES
}

\author{
Mario Plenković1, Daria Mustić2, Slobodan Hadžić3 \\ Faculty of Graphic Arts, University of Zagreb, Zagreb, Croatia \& Alma Mater Europaea - ECM E University of Maribor, \\ Faculty of Electrical Engineering and Computer Science, Institute of Media Communications, Maribor, Slovenia ${ }^{1}$, Faculty of \\ Graphic Arts, University of Zagreb, Zagreb, Croatia ${ }^{2}$; PressCut, Zagreb, Croatia ${ }^{3}$
}

\begin{abstract}
Visual elements of the message are functional only if the criteria of graphic design and communicational structure are appreciated, which are taking psychophysiological characteristic of the human eye into consideration, basic laws of perception and outside factors (media, place of the message). The paper is dealing with the problem of successful usage of visual elements in outdoor advertising on the example of billboards of croatian parliamentary parties in the time of the parliamentary elections. The research is aimed questioning are the political parties
\end{abstract}


Mario Plenković, Daria Mustić, Slobodan Hadžić: METODOLOŠKI OKVIR ZA KOMUNIKOLOŠKU PROCJENU USPJEŠNOSTI VIZUALNIH KRITERIJA PARLAMENTARNIH STRANAKA U IZBORNIM KAMPANJAMA

Media, Culture and Public Relations, 11, 2020, 2

designed their billboards using professional standards of graphic design. The paper is exploring success in designing key visual elements. Theory discussion is conducted thru forming and analysis of the structure of professional criteria for the usage of visual elements and analysis of their application on billboards of parliamentary parties.

Key words

Communication science, methodological framework, visual criteria, posters, parliamentary parties, election campaigns

First published in Informatologia, Vol. 41 No. 4, 2008 